\title{
Asymptomatic and Pre-Symptomatic COVID-19 in China
}

\author{
Zunyou $\mathrm{Wu}^{*}$ and Jennifer M. McGoogan
}

Keywords: Novel coronavirus disease 2019, Asymptomatic, Pre-symptomatic, Transmission

As the novel coronavirus disease 2019 (COVID-19) pandemic spreads rapidly across the globe many unanswered questions about the basic biology and epidemiology of the disease hamper our response strategies and limit our ability to achieve control and prevent a rebound or so-called "second wave". One such crucial question is: To what degree do asymptomatic cases contribute to transmission? Early, small studies on this subject have found wide ranging estimates of the prevalence of asymptomatic carriers, and just a handful of studies so far have documented viral shedding by asymptomatic cases [1]. We recently re-examined China's COVID-19 case report data to investigate this question [2]. This Editorial aims to describe how asymptomatic cases contribute to transmission and what the implications are for control strategies.

Asymptomatic COVID-19 cases are those having positive results from either viral nucleic acid or antibody testing yet not having classical symptoms (i.e., fever, dry cough, fatigue). In a report of the first 72,314 COVID-19 cases in China, the proportion of such asymptomatic cases was $1 \%$ - only 889 cases had been documented $[3,4]$. However, these researchers underscored the high likelihood of this being an understatement of the true prevalence of asymptomatic infection because of the inherent difficulty of finding these cases [3, 4]. Also, it should be noted that community transmission in China was limited primarily to Wuhan City, and to a lesser extent in Hubei Province, while the 30 other

\footnotetext{
* Correspondence: wuzy@263.net

National Center for AIDS/STD Control and Prevention, Chinese Center for Disease Control and Prevention, 155 Changbai Road, Changping District, Beijing 102206, China
}

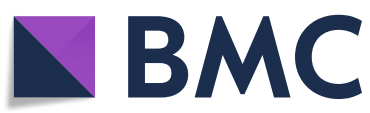

(c) The Author(s). 2020 Open Access This article is licensed under a Creative Commons Attribution 4.0 International License, which permits use, sharing, adaptation, distribution and reproduction in any medium or format, as long as you give appropriate credit to the original author(s) and the source, provide a link to the Creative Commons licence, and indicate if changes were made. The images or other third party material in this article are included in the article's Creative Commons licence, unless indicated otherwise in a credit line to the material. If material is not included in the article's Creative Commons licence and your intended use is not permitted by statutory regulation or exceeds the permitted use, you will need to obtain permission directly from the copyright holder. To view a copy of this licence, visit http://creativecommons.org/licenses/by/4.0/. The Creative Commons Public Domain Dedication waiver (http://creativecommons.org/publicdomain/zero/1.0/) applies to the data made available in this article, unless otherwise stated in a credit line to the data. had clusters of cases. The prevalence of asymptomatic cases may differ in areas with versus without community transmission. Indeed, until recently asymptomatic cases were only being found through rapid screening of close contacts of symptomatic cases, intensive investigation of case clusters, and active testing campaigns [5].

Not surprisingly, one important finding that has come to light over the past two months is that only a portion of cases in China originally categorized as asymptomatic are "true" asymptomatic cases. Even after an extended period of close medical observation, these individuals never become ill with COVID-19 symptoms, yet they eventually produce detectable levels of specific antibodies. Other individuals who have been identified as asymptomatic at their initial RT-PCR screening, were likely in the virus incubation period. Thus, they were not asymptomatic, but pre-symptomatic, and they eventually experienced the onset of symptoms, which meant that they were reclassified into one of the other case definitions (i.e., mild, moderate, severe, critical) [5].

As of April 7, 2020, a total of 81802 COVID-19 cases had been reported in China. This total included 1190 asymptomatic cases that had been confirmed as asymptomatic after extended close follow-up. It also included a further 1095 cases that had been tentatively categorized as asymptomatic cases but were still under medical observation [6]. These findings place the prevalence of "true" asymptomatic infection in the range of 1.5 to $2.8 \%$. Nevertheless, this is clearly still an underestimate since testing has primarily occurred among individuals who have symptoms. Interestingly, the new widespread 
active testing campaign currently underway in Wuhan ( $\sim 11$ million residents planned to be tested over 10 days) may provide important new evidence on the prevalence of carriers. Meanwhile, asymptomatic and pre-symptomatic cases are beginning to be documented in other settings as well, for example, in a long-term care facility in the United States [7].

As for the infectiousness of asymptomatic or presymptomatic cases, it is important to note that presence of viral RNA (i.e., positive viral nucleic acid test result) does not necessarily indicate the presence of viable, transmissible virus [8]. Yet, transmission events have been documented in various contexts in China [6], and now elsewhere as well [9], wherein asymptomatic or presymptomatic individuals successfully pass their infection on to close contacts. Transmission in this context is almost certainly a driver of local outbreaks and epidemics and thereby contributes to the global pandemic. The magnitude of its contribution to the epidemic was not significant in China according to the limited available data; however, it remains unknown in other countries. Large scale serological studies, which will help our understanding of transmission by carriers, are underway in China and Germany and regionally in the United States, and their results are anxiously awaited.

Despite the epidemic being under control in China, most Chinese citizens are still susceptible to COVID-19 and people are extremely concerned about a resurgence that could be sparked by undetected transmission by asymptomatic and pre-symptomatic individuals. But China is not alone. Many other countries, particularly low- and middle-income countries the world over, must also be vigilant with respect to this silent danger [10]. The stakes are high in these countries, where many live in crowded and impoverished communities and cannot easily adopt personal hygiene and social distancing measures. Moreover, the communities themselves may struggle to implement environmental disinfection procedures; testing, isolation, contact tracing, and quarantine; or engage in community containment actions. Sadly, without these nonpharmacological interventions, and without vaccines and therapeutics, and without a strong healthcare system, these communities will likely suffer the worst of what COVID-19 brings.

\section{Acknowledgement}

Not applicable

\section{Authors' contributions}

ZW conceptualized the paper. ZW and JMM drafted, revised, and finalized the paper. The authors read and approved the final manuscript.

\section{Authors' information}

The views and opinions expressed herein belong to the authors alone, and do not represent the official policy, or endorsement of their affiliated institutions.

\section{Funding}

This work was supported by the National Health Commission (grant number 2018ZX10721102) and National Ministry of Science and Technology of the People's Republic of China (grant number 2020YFC0846300). The funding body had no role in the writing of this manuscript.

Availability of data and materials

Data sharing is not applicable to this article as no datasets were generated or analyzed during the current study.

Ethics approval and consent to participate

Not applicable

Consent for publication

Not applicable

\section{Competing interests}

The author declares no competing interests.

Received: 18 May 2020 Accepted: 18 May 2020

Published online: 22 June 2020

\section{References}

1. Qiu J. Covert coronavirus infections could be seeding new outbreaks. Nature. 2020. https://doi.org/10.1038/d41586-020-00822-x.

2. Wu Z. Asymptomatic and pre-symptomatic cases of COVID-19 contribution to spreading the epidemic and need for targeted control strategies. Chin J Epidmiol. 2020;41:E036.

3. The Novel Coronavirus Pneumonia Emergency Response Epidemiology Team. The epidemiological characteristics of an outbreak of 2019 novel coronavirus diseases (COVID-19)—China, 2020. China CDC Weekly. 2020;2: $113-22$.

4. Wu Z, McGoogan JM. Characteristics of and important lessons from the coronavirus disease 2019 (COVID-19) outbreak in China: summary of a report of 72314 cases from the Chinese Center for Disease Control and Prevention. JAMA. 2020;323:1239-42.

5. Hu Z, Song C, Xu C, Jin G, Chen Y, Xin X, et al. Clinical characteristics of 24 asymptomatic infections with COVID-19 screened among close contacts in Nanjing, China. Sci China Life Sci. 2020;63:706-11.

6. National Health Commission of the People's Republic of China. Update on COVID-19 in China as of 24th hour on April 7, 2020. Beijing, China: National Health Commission; 2020. http://www.nhc.gov.cn/xcs/yqfkdt/202004/5e2b6 fobd47d48559582242e3878447d.shtml.

7. Kimball A, Hatfield KM, Arons M, James A, Taylor J, Spicer K, et al. Asymptomatic and presymptomatic SARS-CoV-2 infections in residents of a long-term care skilled nursing facility - King County, Washington, March 2020. MMWR Morb Mortal Wkly Rep. 2020;69:377-81.

8. Wölfel R, Corman VM, Guggemos W, Seilmaier M, Zange S, Müller MA, et al. Virological assessment of hospitalized patients with COVID-2019. Nature. 2020. https://doi.org/10.1038/s41586-020-2196-X.

9. Rothe C, Schunk M, Sothmann P, Bretzel G, Froeschl G, Wallrauch C, et al. Transmission of 2019-nCoV infection from an asymptomatic contact in Germany. N Engl J Med. 2020;382:970-1.

10. Qian $X$, Ren R, Wang YF, Guo Y, Fang J, Wu ZD, et al. Fighting against the common enemy of COVID-19: a practice of building a community with a shared future for mankind. Infect Dis Poverty. 2020;9:34 https://doi.org/10. 1186/s40249-020-00650-1.

Ready to submit your research? Choose BMC and benefit from:

- fast, convenient online submission

- thorough peer review by experienced researchers in your field

- rapid publication on acceptance

- support for research data, including large and complex data types

- gold Open Access which fosters wider collaboration and increased citations

- maximum visibility for your research: over 100M website views per year

At $B M C$, research is always in progress.

Learn more biomedcentral.com/submissions 